\title{
Biodiesel: Freedom from Dependence on Fossil Fuels?
}

\author{
*B. Anjan Kumar Prusty ${ }^{1,2}$, Rachna Chandra ${ }^{1}$ and P. A. Azeez \\ ${ }^{1}$ Environmental Impact Assessment Division, \\ Sálim Alicenter for Ornithology and Natural History ( SACON), \\ Anaikatty (PO), Coimbatore - 641108, India \\ ${ }^{2}$ Present Address: Gujarat Institute of Desert Ecology, \\ Post Box \# 83, Opp. Changleswar Temple, Mundra Road, Bhuj-370001, Gujarat, \\ India \\ *AllCorrespondence \\ Email:anjaneia@gmail.com
}

\begin{abstract}
In view of the depleting oil reserves and exponential rise in petroleum prices, the search for alternative sources of fuel is very timely and important. The present paper addresses the underlying issues in biodiesel production from biomaterials and sustainable production and supply of firstgeneration biofuels, especially the one from jatropha. The agencies and research institutions involved in the production of biofuels and the national and international effortsmade in this regard are discussed here. There is also a dire need of a step towards large-scale production and supply of secondgeneration biofuels, although in infant stage, to strengthen the world economy in general and Indian economy in particular. However, the production of biofuels are likely to have serious socio-economic implications especially to the lesser developed societies. This needs serious attention from policy makers and public at large.
\end{abstract}

Key words: Biodiesel, biofuel, jatropha, firstgeneration biofuels, and second-generation biofuels.

\section{Introduction}

To cater to the increasing transport requirements of the rising population, the number of automobiles has risen in world in general and India in particular after the 
general economic liberalization in the country in the early $1990 \mathrm{~s}$ (Mohanraj and Azeez 2005). Since the 1970s, the world's attention has been focused on depleting oil reserves, rising demand for petroleum products and the consequent hike in petroleum prices. It appears that the price of crude oil will remain increasing and volatilefor a long time to come; the price was US\$ 3.05 in 1973 , currently hovering around US\$ 90 per barrel. Our dependence on petroleum for fuelling the transportation and other sectors of human activity threatens energy security and affects the environment and the growth of world economy. Further, the politics of oil have caused most of the international conflicts in the last few decades, and left millions of people dead and many more disabled. The issue of energy security led governments and researchers to look for alternate means of renewable and environment-friendly fuels. Biofuel has been one of the promising, and economically viable alternatives. Developing the technology to produce and use biofuels will create fuel options that can positively influence establishing a safer, cleaner and sustainable alternative to petroleum. Gone are the days of growing edible crops just for food; now there are crops from which fuelcan be extracted and taken to the fuel tank. However, the growing interest in biofuels, if not appropriately regulated and managed is likely to deprive lesser developed billions of peoples of theirfood crops. So far as biofuels are not based on maze or other food crops and so far as cultivation of the biofuels do not lead to diversion of lands available for food crops promotion of biofuels are welcome.

The concept of biofuel dates back to 1885 when Dr. Rudolf Diesel built the first diesel compression ignition engine with full intention of running it on vegetative source (Shay 1993). In 1912, he observed, “... the use of vegetable oils for engine fuels may seem insignificant today. But such oilsmay in the course of time become as important as petroleum and the coal tar products of present time." However, due to cheap petroleum products, and probably due to economic might of the cartels, investigations of such non-conventional fuels never took off to offer any viable ideas. However, it appears the trend has changed, after the world realized that oil resources are almost in the path of exhaustion and cannot sustain the world economy formore than about halfa centaury. In 1970 , researchers have found that 
a simple chemical process could reduce the viscosity of vegetable oils and itcould perform like diesel fuel in modern internal combustion engines. Since then the technical developments have come a long way and the plant oil today has been highly established as biofuel, equivalent to diesel.

Recent environmental (e.g. Kyoto Protocol, Cunningham and Cunningham 2002 ) and economic concerns have prompted resurgence in the use of biodiesel throughout the world. USA and several European countries are already working towards substituting petroleum fuel by such alternatives. In 1991, the European Community proposed a 90 per cent tax reduction for using biofuels, including biodiesel and is targeting to reduce consumption of petroleum fuel at least by around 5 per cent, by substituting with biofuel by the year 2010 (Shanker and Dhyani 2006). Today, 21 countries worldwide produce biodiesel. India is one of the largest petroleum consuming and importing countries. India imports about 70 per cent of its petroleum demands. Currently Indian annual requirement for Petroleum products is about 120 million metric tons of which the diesel consumption is approximately 40 million tones.

\section{Alternative Fuel - the Biofuel}

Alternative fuels are fuels that are not composed substantiallyof petroleum and thus are alternatives to petroleum. As a substitute to the 'traditional' fuel, itis expected to yield significant energy security and environmental benefits to nations. Biofuel, the term coined in late 1980s, refers to renewable fuels generally derived from biomass and primarilyused for motive, thermal and power generation, with quality specifications in accordance with the International Standards. Biofuels can be derived from agricultural crops such as corn, soybeans and sugarcane, or from biomass resources such as agricultural, wood, animal and municipal wastes (Sudarsan and Anupama 2006), and these are the firstgeneration biofuels. As much of the waste is comprised of lignocellulosic material, itcan be converted into biofuels. The two most common biofuels used in transport sector, i.e., ethanol and biodiesel, are ecofriendly and can be used as substitutes for gasoline and diesel or are blended with them so that greenhouse gas emission can be reduced and thus 
help in improvement of ambient airand water quality.Biodiesel is a renewable liquid fuel that can be produced locally, helping reduce the country's dependence on imported crude oil.

Biodiesel as defined by the World Customs Organization (WCO) is "a mixture of mono-alkyl esters of long-chain [C16-18] fatty acids derived from vegetable oils or animal fats, which is a domestic renewable fuel for diesel engines and which meets the international specifications (ASTM D 6751)."Biodiesel, derived from the oils and fats of plants like soybean, cotton, sunflower, jojoba, rapeseed, canola, Jatropha curcas (Peterson et al.1983, Schlautman et al.1986, Yong 1998, Alhasan et al. 2005 ) and animal fat can be used as a substitute or an additive to diesel. It has almost no sulphur and has about $10 \%$ built in oxygen. As an alternative fuel, biodiesel can provide power similar to conventional diesel fuel. The conversion process of vegetable oil into biodiesel is very efficient, in nearly 1-to-1 ratio, which means 1 gallon of vegetable oilwillproduce almost 1 gallon of biodiesel. Biodiesel can be used at a 100 percent level or mixed with diesel at any rate. Pure or 100 per cent biofuel is designated as $\mathrm{BXX}$ where $\mathrm{XX}$ indicates the volumetric percentage biofuel contained in the blend (Mohammed et al.2006). The most common mixtures are B2 containing 2 per cent biodiesel and B20 containing 20 per cent biodiesel (Coltrain 2002). A B2 mixture increases fuel lubricity to acceptable levels even with reduced sulfurcontent of diesel.

\section{Biodiesel: Characteristics and Specifications}

As biodiesel is produced from a wide variety of vegetable oils of varying origin and quality, itwas necessary to implement criteria for standardization of fuel quality for better engine performance. Austriawas the pioneering country in the world to define and approve the standards for rapeseed oilmethyl esters as diesel fuel (Meher et al. $2006)$. As standardization is a prerequisite for qualitycontrol,certain parameters are considered for the purpose, of which cetane number and fuel viscosityare important ones. The detailed physical attributes of biodiesel produced following the transesterification process given in Table 1 and Table 2 depicts the vegetable oil 
specific parameters and the corresponding value of fatty acid methyl esters according to select countries. 
Table 1. Parameters for the Quality of Biodiesel

\begin{tabular}{|c|c|c|c|c|c|c|}
\hline Parameters & $\begin{array}{l}\text { Austri } \\
\text { a (ON) }\end{array}$ & $\begin{array}{l}\text { Czech } \\
\text { republic } \\
\text { (CSN) }\end{array}$ & $\begin{array}{c}\text { France } \\
\text { (journal } \\
\text { official) }\end{array}$ & $\begin{array}{c}\text { Germany } \\
\text { (DIN) }\end{array}$ & $\begin{array}{l}\text { Italy } \\
\text { (UNI) }\end{array}$ & $\begin{array}{c}\text { USA } \\
\text { (ASTM) }\end{array}$ \\
\hline Density at $15 \circ \mathrm{C} \quad\left(\mathrm{g} / \mathrm{cm}^{3}\right)$ & $\begin{array}{l}0.85- \\
0.89 \\
\end{array}$ & $0.87-0.89$ & $0.87-0.89$ & $\begin{array}{c}0.875- \\
0.89\end{array}$ & $0.86-0.90$ & - \\
\hline Viscosity at $40 \cong \mathrm{C}\left(\mathrm{mm}^{2} / \mathrm{s}\right)$ & $3.5-5.0$ & $3.5-5.0$ & $3.5-5.0$ & $3.5-5.0$ & $3.5-5.0$ & $1.9-6.0$ \\
\hline Flash point ( $\cong \mathrm{C})$ & 100 & 110 & 100 & 110 & 100 & 130 \\
\hline CFP P $(\stackrel{\text { C })}{ }$ & $0 / \mathrm{K} 5$ & $\mathrm{~K} 5$ & - & $0-10 / \mathrm{K} 20$ & - & - \\
\hline Pour point ( $(\underline{C})$ & - & - & $\mathrm{K} 10$ & - & $0 /-5$ & - \\
\hline Cetane number & $\geq 49$ & $\geq 48$ & $\geq 49$ & $\geq 49$ & - & $\geq 47$ \\
\hline $\begin{array}{l}\text { Neutralization number (mg } \\
\text { KOH/g) }\end{array}$ & $\leq 0.8$ & $\leq 0.5$ & $\leq 0.5$ & $\leq 0.5$ & $\leq 0.5$ & $\leq 0.8$ \\
\hline Conradson carbon residue ( $\%$ ) & 0.05 & 0.05 & - & 0.05 & - & 0.05 \\
\hline
\end{tabular}

Table 2. Specific Parameters of Vegetable oil to have the Quality of Biodiesel

\begin{tabular}{|l|c|c|c|c|c|}
\hline Parameters & $\begin{array}{c}\text { Austr } \\
\text { ia }\end{array}$ & $\begin{array}{c}\text { Czech } \\
\text { republic } \\
\text { (ON) }\end{array}$ & $\begin{array}{c}\text { France } \\
\text { (CSN) }\end{array}$ & German & $\begin{array}{c}\text { Italy } \\
\text { (UNI) }\end{array}$ \\
(ASTM) \\
(DIN)
\end{tabular}

\section{Selection Process for Biofuel Production}

As investigated by several researchers, there are many plants, which contain hydrocarbons and other substances close to petroleum in their chemical composition. Such plant species are common in Asia and Pacific region (Ananthakrishnan 1982). The species, which are cost effective, non-food crop, fast growing and early fruiting, with high oil content, non-toxic and biodegradable are generally preferred as a source for biofuel. Under Indian conditions such plants varieties, which are non-edible, can be grown abundantly on large-scale in wastelands and have the potential to be cracked into gasoline fractions, can be 
considered for biodiesel production. Some of the prominent non-edible oil seed producing plants include Azadirachta indica (Neem), Boswellia ovalifololata, Calophyllum inophyllum (Nagchampa), Calotropis gigantia (Aak), Euphorbia tirucalli (Sher), Hevea brasiliensis (Rubber), Jatropha curcas (Physic nut) and Pongamia pinnata (Karanj) (Sudarsan and Anupama 2006).

\section{Jatropha curcas: One of the options}

Considering all the options available among non-edible tree bearing oil (TBO) seeds, Jatropha curcas L. has been identified as the most suitable seed. Jatropha is a genus of approximately 175 succulents, shrubs and trees from the family Euphorbiaceae and is thus closely related to other important cultivated plants like rubber and caster. Originating in the Caribbean, the Jatropha had been spread as a valuable hedge plant to Africa, Asia and to India by Portuguese traders. Since its introduction by Portuguese traders in 16th century in India, Jatropha has been grown as a medicinal plant and a hedge crop. Presently nine species of Jatropha thrive in India's varied regional climates (Shanker and Dhyani 2006), viz. J. integerrima, J. gossypifolia, J. glandulifera, J. tanjorensis, J. multifida, J. podagrica, J. Villosa, J. villosa ssp. ramnadensis and $J$. maheswarii. of these, $J$. curcas is a widely occurring variety of TBO. Itgrows practicallyallover India under a variety of agroclimatic conditions and thus ensures a reasonable production of seeds with very littleinputs.

Some of the advantages of the species are listed below:

- Jatropha can be grown in arid zones (20 cm rainfall)as well as in higher rainfallzones and even on land with thin soilcover.

- Itis a quick yielding species even in adverse land situations, viz. degraded and barren lands under forest and non-forest use, dry and drought prone areas, marginal lands, even on alkaline soils and also as agro-forestrycrops. Jatropha can be a good plantation material for eco-restoration in alltypes of wasteland. 
- Jatropha grows readily from plant cuttings or seeds up to the height of 3-5 $\mathrm{m}$.

- Jatropha is not considered a good forage material and hence is generally grown as a live fence for protection of agricultural fields from damage by livestock

- The seed oil is also reported to possess insecticidal, molluscicidal, fungicidal and nematicidal properties.

- The plant is highly pest and disease resistant.

- Various parts of the plant are of medicinal value, its bark contains tannin, the flowers attractbees and thus the plant has honey production potential.

- Jatropha helps in sequestration of atmospheric carbon and assists in the build up of totalsoilcarbon.

- Being rich in nitrogen, the seed cake is excellentorganic manure.

The Jatropha suffers from certain limiting factors, which need to be kept in mind while dealing with the species. These are as follows:

- Jatropha cannot be grown on waterlogged lands and slopes exceeding 30 degree.

- The ideal climatic conditions for Jatropha can be summarized as annual rainfallnot exceeding $600 \mathrm{~mm}$ inmoderate climatic conditions, $1200 \mathrm{~mm}$ in hot climatic zones and soil pH less than 9. The atmospheric temperature should not fallbelow $0^{\circ} \mathrm{C}$, as the plants are sensitive to ground frost that may occur in winters.

- Jatropha seeds are hard and toxic.

- The golden flea beetle (Podagrica sp.) can harm particularlyyoung plants.

- Jatropha is also a host to the fungus 'frogeye' (Cercospera sp.), common in tobacco.

\section{Jatropha Cultivation: Yield and Productivity}

Apart from planting the seeds, Jatropha can be propagated vegetatively. Use of branch cutting for propagation results in rapid growth and the bush can be expected 
to bear fruitwithin one year. Seeds are best sown during mid-February to mid-March and the seedlings of 60-75 $\mathrm{cm}$ tallcan be transplanted to the field.The ideal planting pitch has been found to be $2 \times 2 \mathrm{~m}$, thus accommodating 2500 plants per hectare. Wider spacing would give larger yields of fruite $794 \mathrm{~kg} / \mathrm{ha}$. Like allperennialplants, Jatropha displays vigorous growth in youth that tails off gradually towards maturity. In equatorial regions where moisture is not a limiting factor (i.e., continuously wet tropics or under irrigation), Jatropha can bloom and produce fruitthroughout the year. To withstand extreme drought conditions, Jatropha plant sheds leaves to conserve moisture, which results in reduced growth. Although Jatropha is adapted to soils with low fertilityand alkalinity, better yields can be obtained on poor qualitysoils iffertilizers containing small amount of nutrients such as calcium, magnesium and sulfurare used for the firsttwo years. Jatropha plant bears fruitfrom second year of itsplantation and the economic yield stabilizes from fourth or fifthyear onwards. The plant has an average lifewith effective yield up to 50 years. Jatropha gives about $2 \mathrm{~kg}$ of seed per plant. In India, in relatively poor soils such as in Kachchh (Gujarat), the yields have been reported to be 1 $\mathrm{kg} /$ individual, while in lateriticsoils of Nashik (Maharashtra), the seed yields have been reported as $0.75-1.00 \mathrm{~kg} /$ individual. Thus, the economic yield can be considered as $0.75-2.00 \mathrm{~kg} /$ individual and 4.00-6.00 MT/hectare/year depending on agro-climactic zone and agriculturalpractices. One hectare of plantation on average soilwillgive 1.6 MT oil.Plantation on poorer soilswillgive $0.9 \mathrm{MT}$ of oilper hectare. The cost of plantation has been estimated as Rs 20,000 per hectare, inclusive of plant material, maintenance for one year, training, overheads, etc. It includes elements such as site preparation, digging of pits, fertilizers, irrigation, weeding, and plant protection for one year, i.e., untilthe stage when itwillstartbearing fruits.

\section{Jatropha Plantation: Current Status}

Four hundred and fiftyspecies of oilyielding plants have been identified in various parts of India. Jatropha has been selected for focused development in the country due to its low gestation period compared to 7-8 yrs for Pongamia. While the Jatropha seeds are used for oilextraction, other parts of the plant such as leaves 
and bark can be used for developing organic dyes, medicines and biogas. India has vast stretches of degraded land, mostly in areas with adverse agro-climatic conditions, where species of Jatropha can be grown easily. Even 30 million hectares of Jatropha cultivation for biodiesel can completely replace the current usage of fuels in India. Use of 11 million hectares of wasteland for Jatropha cultivation can lead to generation of minimum 12 million jobs.

Central Salt \& Marine Chemical Research Institute (CSMCRI) in India has successfully cultivated good varieties of $J$. Curcas on marginal land to assess practicallyrealizable seed yields. GB Pant University has planted Jatropha in 140 ha at its farm. The university scientists have selected new high yielding species of Jatropha, which have yield potential of up to 10 tons/ha. Efforts of National Oilseed and Vegetable Oil Development (NOVOD) Board in India include development of quality planting material, improved Jatropha seeds having oil contents up to 1.5 times of ordinary seeds, etc. The Board has planned Jatropha plantation at 1,719 ha invarious states.

Biodiesel Technologies, Kolkata, a consortium of tea planters, agriculturalscientists and chemical engineers engaged in the study and research of cultivation of Jatropha / safed musli / stevia / patchouli / vanila, have developed efficientbiodiesel processing reactors indigenously. Nandan Bioagro and Labland Biotech have tied up with British Oil Company, D1 Oils, to cultivate Jatropha. The company will facilitate cultivating the crop. Godrej Agrovet Ltd. is planning to invest over Rs 5 billion, for Jatropha and palm oilcultivation in the states of Gujarat and Mizoram. Emami Ltd, one of the leading toiletriesoutfitin the country, is planning to invest in cultivating Jatropha. The company plans a joint venture with a leading European company to cultivate Jatropha in Suri in West Bengal and Balasore in Orissa. For technical collaboration for extraction of Jatropha oil, Emami plans to approach companies in US, UK and Austria. 
In India, the Jatropha system hypothesizes that it creates a positive reciprocity between raw material/ energy production and environment / food production, i.e., the more energy Jatropha hedges produce the more food crops are protected from animals and erosion. In addition, additional income is created, mainly for women. The plantation has been planned in a total of 4,00,000 hectares of land in the country with the specificobjectives of (i) increasing the yield of Jatropha plants by using good planting material, (ii)selection of varieties / strains, which have more seed content, and (iii) development of processing techniques, which results in maximum oilrecovery from seeds.

\section{Production of Biodiesel from Jatropha}

The production of biodiesel from Jatropha is a systematic process starting from seed preparation to processing and filtration of oil.The process flow diagram of this process, the transesterification process, is given in Figure 1. Transesterification, also called alcoholysis, is the chemical displacement of alcohol from an ester by another alcohol in a process similar to that of hydrolysis (Figure 2 ). Methanol is most commonly used for the purpose because of itscheap cost and availability. Ethanol and higher alcohols such as isopropanol, butanol can also be used for the esterification. Using higher molecular weight alcohols improves the cold flow properties of biodiesel but reduces the efficiency of transesterification process. The process is faster when catalyzed by alkali (Freedman et al.1986) and hence the alkalicatalyzed transesterification process (Figure 3 ) is widely used for the purpose. Several factors known to affect the transesterification process (Hofman et al.2006) are (i) oil temperature, (ii) reaction temperature, (iii) ratio of alcohol to oil, (iv) catalyst type and concentration, (v) intensityof mixing, and (vi)purityof reactants.

Expellers or continuous screw presses are used throughout the world for the extraction of oilfrom soybean, copra, palm kernels, peanuts, cotton seeds, flaxseed and almost every other variety of seeds (Schlautman et al.1986), wherever there is a large enough seed supply to justifya continuous operation. An expellercan exert greater pressure on the seed cake than a hydraulic press. This increased pressure permits recovery of larger proportion of the oil, leaving only 3-4 per cent of the oilin 
the cake with an expeller, compared to 4-6 per cent with a hydraulic press. The expeller is an essentialpart of almost allmodern oilseed extraction plants. Itis used both by itselfand as a pre-press before solvent extraction. Expellers vary in size from machines that process 100 pounds of seed per hour, to machines that process 10 or more tons of seed per hour. Different types of oilexpellers for Jatropha seeds are built in many countries. The two most commonly used expellers are Sayari expeller (Screw cage type) and Komet oilexpeller (Screw squeeze type). Some of the worldwide providers of biodiesel technology are Lurgi PSI, Superior Process Technologies, Biodiesel Industries, Cimbria Sket - Bratney, Crown Iron Works and Renewable Energy Group.

\section{Transesterification: Industrial Practice - Lurgi Process}

Lurgi's process of transesterification is most widely used for the production of biodiesel that involves intensive mixing of methanol with the oil in presence of a catalyst and then separation of lighter methyl ester phase by gravity from the heavier glycerol. For the scope of the paper, the details of the process are not discussed here. Certain key features of Lurgi'sbiodiesel process are as follows:

Technology applicable to multiple feedstocks.

Continuous process at atmospheric pressure and at $60^{\circ} \mathrm{C}$.

Dual Reactor system operating with a patented Glycerin Cross Flow configuration formaximized conversion.

Recovery and recycling of methanol.

Closed loop water wash recycle to minimize wastewater.

Phase separation by gravityprocess (no centrifuges necessary).

Almost all the biodiesel is produced using the base catalyzed transesterification process, as it is the most economical one requiring only low temperatures and pressures with 98 per cent yield. Other processes under development include biocatalyzed transesterification, pyrolysis of vegetable oil/seeds and transesterification in supercriticalmethanol (Saka and Kusdiana 2001 , Kusdiana and 
Saka 2001). The critical issues underlying the transesterification process are: interference of free fatty acid (FFA) with transesterification deactivates the basic catalystresulting in loss of catalyst and biodiesel yield; (ii)as water content of the oil deactivates catalysts, drying of oilmay be required; and (iii)soaps formed with basic catalystare difficultto remove (Canakci and Gerpen 2001, Dorado et al.2002).
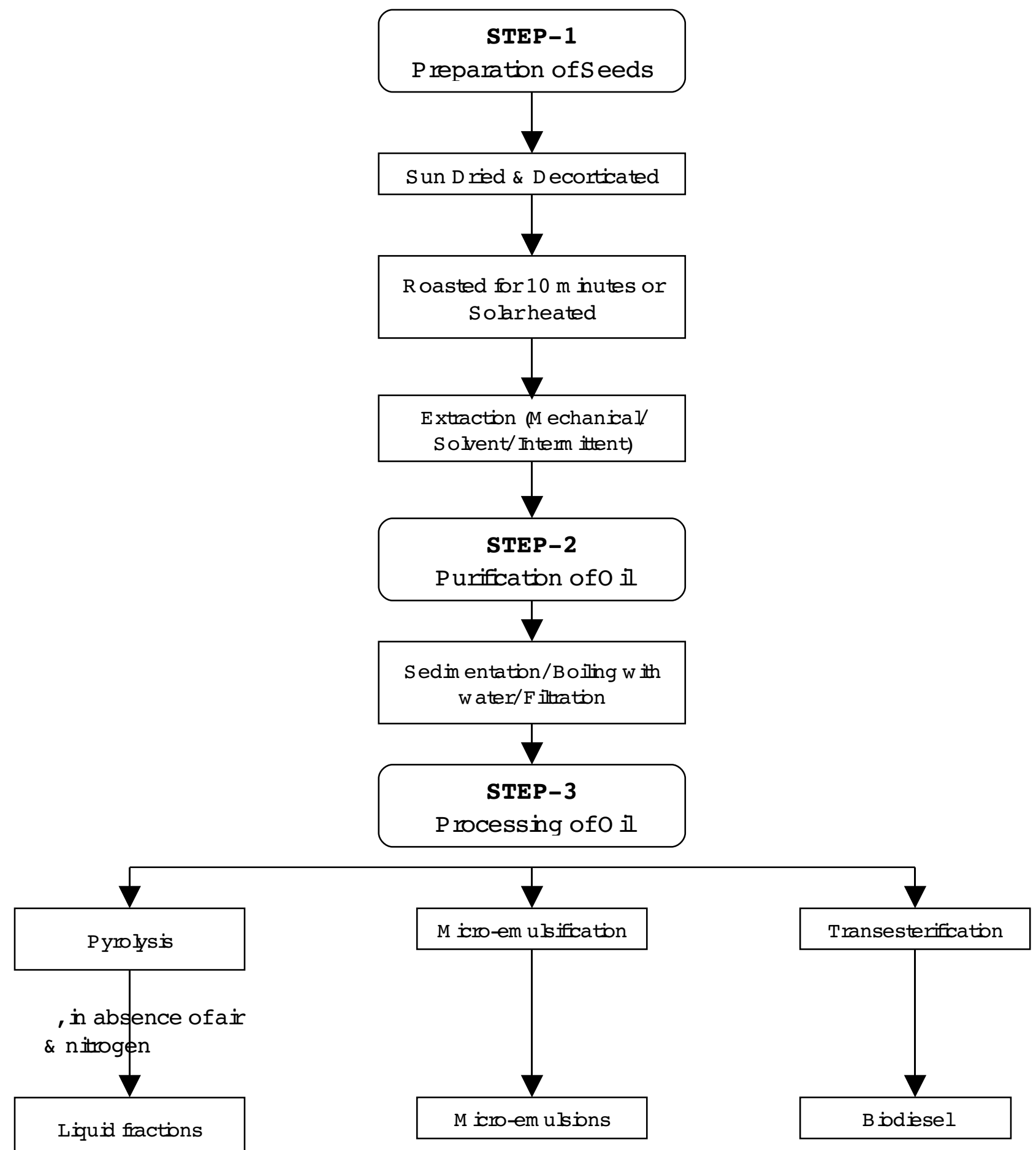
Figure 1. Process flow chart of Jatropha to Biodiesel: Process Steps 


\begin{tabular}{|c|c|c|c|c|c|c|}
\hline \multirow[b]{2}{*}{$\mathbf{R C O O R}^{1}$} & & & Catalyst & \multirow[b]{2}{*}{$\mathbf{R C O O R}^{2}$} & \multirow[b]{2}{*}{+} & \multirow[b]{2}{*}{$\mathbf{R}^{\prime} \quad \mathbf{O H}$} \\
\hline & + & $\mathrm{R}^{2} \mathrm{OH}$ & $\stackrel{\sim}{\longrightarrow}$ & & & \\
\hline Ester & & Alcoho & & Ester & & Alcohol \\
\hline & & 1 & & & & \\
\hline
\end{tabular}

\section{Figure 2. General equation for transesterification}

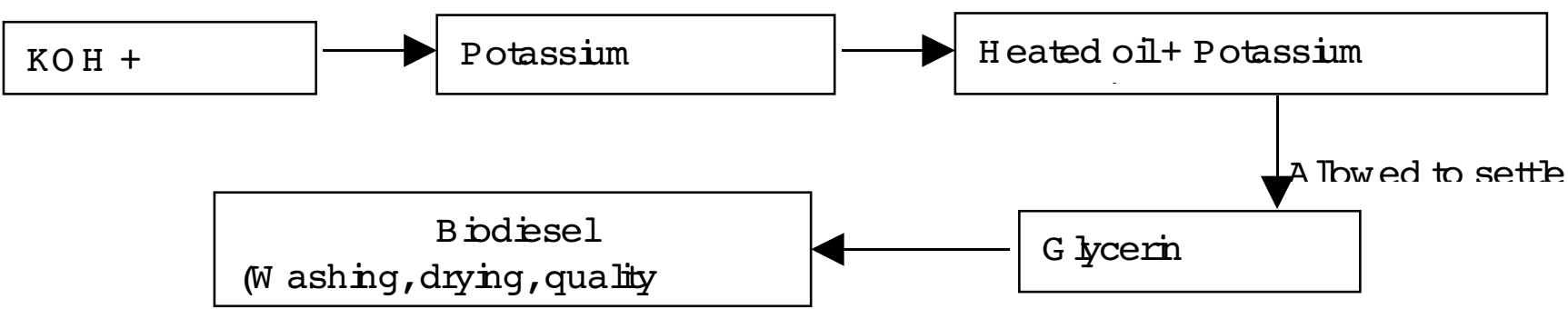

\section{Figure 3. Process flow diagram for the alkali catalyzed transesterification process}

\section{Transesterification Process: Current Status}

A bench scale process was developed for catalyst free transesterification of Jatropha seed oil, other vegetable oils, acid oil, etc. at Indian Institute of che mical Technology (IICT), Hyderabad. The crude product is further processed to obtain biodiesel meeting ASTM specifications. IICT is working on the development of a green process for biodiesel using solid catalysts and enzymes. The Department of Bio-energy, Tamil Nadu Agricultural University (TNAU), Coimbatore has studied different variations of methanol, sodium hydroxide, reaction time and reaction temperature to optimize the process conditions formaximum biodieselyield for alkali catalyzed transesterification of Jatropha oil (Personal communication). An average biodiesel yield of 96 per cent was obtained in an up-scaled biodiesel plant of TNAU. Their pilotplant with a capacity of 250 liters/day consists of a biodiesel reactor with heating and agitating devices, catalyst mixing tank, glycerol settling tanks and biodiesel washing tank. The properties of the biodiesel (free fatty acid, acid value) were found to be within specified limits. Transesterification process has been optimized and patented by R\&D Centre of Indian Oil Corporation Limited (IOCL). Technology know-how has been transferred to M/s. Venus Ethoxyethers, Goa for 
commercialization. CSMCRI has developed a simplified process for biodiesel production from the oilcomplying with Euro-3 specifications for free fattyacid methyl ester. An important objective has been to identifyoutlets for byproducts to enhance the overall value of the seed and thereby make Jatropha cultivation more remunerative. While biodiesel conforming to Euro-3 specifications is produced in Europe from rapeseed oil, this is the first time that such biodiesel has been made from Jatropha oil. The biodiesel developed by CSMCRI has been evaluated at Daimler Chrysler AG and found to be fitting allspecifications. The cetane number has been established to be 58.5. Delhicollege of Engineering has established small capacities of $5,10,50$ and 100 liters batch reactors.

\section{Byproducts}

Although the use of biodiesel seems to be promising one, unless the by and co products could be utilized and marketed on a large scale, the farmers cannot be paid a sustainable price. Proper marketing of byproducts is necessary for economic viability. The common byproducts produced while processing the biodiesel are Glycerol (Kurkiet al.2006) and oilseed cake (Sudarsan and Anupama 2006). While producing $1 \mathrm{MT}$ of clean Jatropha oil, $1.9 \mathrm{MT}$ of oilseed cake excluding shell and 0.095 MT of glycerol could be obtained as byproducts. The byproducts derived from biodiesel processing can also find uses in several ways such as (i) insecticides and molluscicides, (ii) soap production, (iii)engine lubrication, and (iv) medicinal and other uses.

\section{Advantages of Biodiesel}

The advantages of biodiesel are enumerated hereunder:

-Biodiesel is non-toxic and ecofriendly, as it produces substantially less carbon monoxide and 100 per cent less sulfur dioxide emissions with no unburnt hydrocarbons, making itthus an ideal fuel for heavily polluted cities (Hofman et al. $2006)$.

- Biodiesel reduces particulate matter content in the ambient air and hence reduces air toxicity (Coltrain 2002). Itprovides a 90 per cent reduction in cancer risks and neonatal defects due to its less polluting combustion. 
- Compared with a spillof petroleum diesel, however, the damage would be less, both because the toxicity of biodiesel to living organisms is less and because it degrades twice as quickly in the environment (Zhang et al.1998).

-Biodiesel is biodegradable and renewable in nature.

-Biodiesel can be used alone or mixed in any ratiowith conventional diesel. The preferred ratio of mixture ranges from 5 to 20 per cent (Hofman et al.2006).

-Biodiesel extends the lifeof diesel engines.

- Biodiesel could be cheaper than conventional diesel and hence has good potentialfor ruralemployment generation (Kurki et al.2006).

\section{Biodiesel: The Energy Balance}

The net energy balance of various ethanol and biodiesel feedstock has been a center of debate within scientificand policy circles. The energy balance denotes to "a comparison of the energy stored in a fuel to the energy required to grow, process and distribute that fuel" (Tickell2000). According to most of the sources, biodiesel provides a positive energy balance: for every unit of energy needed to produce biodiesel, 2.5 to 3.2 units of energy are gained. Evidence suggests that virgin oil from sources other than soya may have even higher energy content. Overall, biodiesel is said to have the highest energy yield than any liquid fuel. Following is a list of fuels with their energy yield level according to the Minnesota Department of Agriculture Website (Groschen R, www. mda.state.mn.us):

- Biodiesel provides an energy yield of 3.2 (soybean oil).

- Bioethanol provides an energy yield of 1.34 .

- Petrodiesel provides an energy yield of 0.843 .

- Petro-gasoline provides an energy yield of 0.805 .

In spite of all the above listed advantages, biodiesel is likely to pose certain environmental problems such as depletion of oxygen in aquatic systems (Steenblik 2006). Being biological in nature, during oil spillage, it undergoes a series of biological degradation and depletes the available dissolved oxygen in the water bodies that would otherwise remain available to aquatic organisms. Since, trees are 
involved in the production of biodiesel itmay affect the environment in the other way due to tree cutting and felling activities.

The efficient storage of biodiesel resources can provide energy security to the country. Although adequate data are not available on the long-term storage of biodiesel and blends, based on the experience, biodiesel can be stored for six months to one year (Hofman et al.2006). Vegetable oilderivatives especiallytend to deteriorate owing to hydrolyticand oxidative reactions. Their degree of unsaturation makes them susceptible to thermal and/or oxidative polymerization, which may lead to the formation of insoluble products that cause problems within the fuel system, especially in the injection pump (Mittelbach and Gangl 2001). As a mild solvent, biodiesel tends to dissolve sediments normally encountered in old diesel storage tanks. Brass, teflon, lead, tin, copper, zinc, etc. oxidize biodiesel and create sediments. The existing storage facilities and infrastructure for petrol and diesel can be used for the biodiesel with minor alterations. For biodiesel storage, shelf lifeand its breakdown under extreme conditions assume importance. The following points meritattention for storage of biodiesel:

Biodiesel has poor oxidation stability. Use of oxidation stabilityadditives is necessary to address this problem.

Low temperature can cause biodiesel to gel, but on warming it liquefies quickly. Hence, insulation/jacketing of storage tanks and pipelines would need to be done at the low temperature zones.

To avoid oxidation and sedimentation of tanks with biodiesel, storage tanks made of aluminum, steel, etc. are recommended for usage.

\section{The Indian Scenario}

There has been greater awareness on biodiesel in India in the recent times and significant activities have picked up for itsproduction especiallywith a view to boost the rural economy. The activities launched in the field of biodiesel in India and the agencies involved therein (Sudarsan and Anupama 2006) include: 
Launching a National Bio-diesel mission to cover 25 lakh ha, by the Planning commission

Launching a bio-diesel procurement policy by the Ministry of Petroleum and NaturalGas, Government of India

Constitution of two national networks, one for development of Jatropha and the other for Pongamia

Development of high quality Jatropha through tissue culture by DBT, Aditya Sheel Biotech, etc

Plantation by NOVOD Board, NAEB, NGOS and several private companies. Pilot plants for biodiesel production by Indian Institute of Technology (IIT), Indian Institute of Petroleum (IIP, Dehradun), R\&D Centre of IOCL, PAU Ludhiana, Indian Institute of Science (IISC), Indian Railways, IICT, CS M C R . Transesterification plants with capacities: $300 \mathrm{MT} / \mathrm{day} \& 30 \mathrm{MT} / \mathrm{day}$ in AP, 5.00 MT/day in Sivakasi, Oil India planning 24 MT/day capacity plants in various states.

Trial runs by Indian Railways, Mahindra \& Mahindra (Tractors), Haryana Roadways/IOCL, BEST Buses/HPCL, Daimler Chryslercars, etc. Supply of biodiesel by Lubrizol India Pvt. Ltd. and Gujarat Oleochem.

The Government of India had proposed a National Mission on biodiesel comprising six micro-missions covering the essential aspects of plantation, seed procurement, oil extraction, transesterification, blending and trade, and R\&D. In this regard, the Government of India has approved the controlled cultivation of plant species such as J. curcas, Pongamia pinnata, Calophyllum inophyllum, Euphorbia tirucalli and Boswellia ovalifololata (Sudarsan and Anupama 2006). Indian Oil, in its R\&D Centre at Faridabad, has worked on the establishment of the production parameters of transesterified Jatropha oiland use. They have been using a laboratory scale plant with a capacity of $100 \mathrm{~kg} /$ day for transesterification and designing of larger capacity plants is underway. Production of biodiesel in smaller plants of capacity, for instance with 5-20 kg/day, may also be started in villages. 
IISc, Bangalore and Tamil Nadu Agriculture University, Coimbatore had carried out substantial developmental activities with regard to the production of biodiesel through transesterified non-edible oil and its use. Kumaraguru College of Technology (KCT) in association with Pan Horti Consultants, Coimbatore has worked on marginally altering the engine parameters to suit the Indian Jatropha seeds and to minimize the cost of transesterification process.

\section{Commercial Production of Biodiesel: Indian Efforts}

Approximately 85 per cent of the operating cost of biodiesel plant in India is the cost to acquire feedstock. Securing own feedstock to insure supply at a fair price and sourcing itlocally to avoid long haulage for delivery of seeds to biodiesel plant are critical factors in controlling profitability. The capital cost both in India and internationally is around Rs 15,000-20,000 per MT of biodiesel produced. At 10000 MTPA, the capital cost of oil extraction and transesterification plant would be Rs 20,000/MT capacity. A plant size of 10,000 MTPA can be considered optimal assuming cost of oilextraction at Rs $2360 / \mathrm{MT}$ and cost of transesterification at Rs $6670 / \mathrm{MT}$ with byproducts produced @ $2.23 \mathrm{MT}$ seed cake/MT of biodiesel and 95 $\mathrm{kg}$ of glycerol per MT of biodiesel. Fixed costs towards manpower, overheads and maintenance is 6 per cent of capitalcost, and depreciation is 6.67 per cent of capital cost. The return on investment (ROI) is 15 per cent pretax on capitalcost. As per the Government of India's Vision document 2020 , cultivating 10 million ha with Jatropha would generate 7.5 million tones of fuel a year, creating year-round jobs for five million people (Shanker and Dhyani 2006). As itstands today, biodiesel produced especially from plants such as Jatropha and Pongamia work out to Rs 30/liter, while the Ministry of Petroleum has approved a price of Rs 25/literfor the biodiesel to be sold through the authorized outlets with effect from January 2006 .

Some of the smallunits that are already incommercial production are:

i. Aatmiya Biofuels Pvt. Ltd., Por-Vadodara, Gujarat had set-up biodiesel plant with a commercial production capacity of 1000 liters/day from Jatropha.

ii. Gujarat oelo Chem Ltd., Panoli based firm started producing biodiesel from vegetable based feedstock in March 2005 . 
BP, formerly British Petroleum, would be funding a project estimated at US $\$ 9.4$ million to TERI in AP to demonstrate feasibility of production of biodiesel from Jatropha. The commercial pilotplant established by Biodiesel Technologies, Kolkata produces 450 liter/day of biodiesel. Diamond Energy Resources Pvt. Ltd has been working on Jatropha plantation and further development since last fifteen years. The company targets to set up three transesterification plants each of 100 TPD capacities. The Southern Online Biotechnologies Ltd is setting up 30 TPD or 90,000 TPA biodiesel plant estimated at Rs 150 million at Choutuppal in AP with technology support from Lurgi.Kochi Refineries Ltd. is setting up a pilotplant of 100 liters/day with a US based company, Team sustain Ltd, to extract biodiesel from rubber seed oil. Shirke Biohealthcare Pvt. Ltd, Pune is setting up a refinery with a capacity to process 5,000 liters biodiesel per day from Jatropha oil. Additionally, the refinery willalso produce $1 \mathrm{MW}$ power with the oilcake and naturalgas, which willbe used to run the power plant. Jain Irrigation System Ltd plans to set up a large-scale commercial biodiesel plant in Chattisgarh by 2008 with a capacity of 150,000 TPD estimated at Rs 480 million. R\&D work has given satisfactory results on 3 TPD biodiesel plant at Jalgaon, which was builtat a cost of Rs 5 million. Nova Bio Fuels Pvt. Ltd plans to set up 30 TPD biodiesel plant in Panipat by the end of 2006 with an investment of Rs 200 million with an aim to market its byproduct glycerin to pharma companies. Naturol Bioenergy Ltd is setting up 300 TPD integrated 100 per cent EOU biodiesel plant in Kakinada, AP at an estimated cost of Rs 1.4 billion. Sagar Jatropha Oil Extractions Pvt. Ltd, Vijayawada is setting up a biodiesel plant at an investment of Rs 100 million.

\section{Biodiesel Usage: Field Trials}

Diesel forms nearly 40 per cent of the energy consumed in the form of fossilfuels and its demand is estimated at 40 million tons. Therefore blending with less expensive alternatives becomes an important national issue, which, apart from giving economic dividends, lowers the country's oil bill. In recent years, trials on automobiles using biodiesel have been conducted by several institutions, viz. IOC, ICAR, IIT-Delhi, which have confirmed that biodiesel can reduce wear and tear of 
engines and reduce oil pollution significantly (Sudarsan and Anupama 2006). Private sector companies have also been focusing theirR\&D work on performance of engine with biodiesel and its pollution characteristics. Some of the major companies taking lead in fieldtrials of biodiesel include Tata Motors Ltd, Mahindra \& Mahindra Ltd, Wartsila India Ltd, etc. At KCT, Coimbatore auto-rickshaw was successfully run on pure biodiesel prepared from Jatropha oil. Trains have successfullybeen run on 5-10 per cent blends of biodiesel in association with IOCL. HPCL is carrying out field trials in association with BEST, Mumbai. Daimler Chrysler India completed firstphase of the field trials on two C-Class Mercedes-Benz cars powered by pure biodiesel and clocked over $5900 \mathrm{~km}$ under hot and humid conditions. CSIR plans to test vehicles on biodiesel developed from Jatropha in association with Tata Motors and IOCL. NOVOD Board has initiated test run by blending 10 per cent of biodiesel in collaboration with IIT, Delhi in Tata Sumo and Swaraj Mazda vehicles. Haryana State Transporthad run buses using biodiesel.

\section{Biodiesel: International Experiences}

Several countries in the world have active biodiesel programs. They also have provided legislative support and have drawn up national polices on biodiesel development. France is the world's largest producer of biodiesel; its conventional diesel contains 2 to 5 per cent biodiesel and that willsoon apply to the whole of Europe. Soya based biodiesel is being produced in USA (Schlautman et al.1986). Rapeseed based biodiesel is in Germany (Meher et al.2006). Germany has more than 1,500 biodiesel filling stations. Sunflower based biodiesel has made good success in France and UK. The fullpotential of jatropha is far from being realized. The Agricultural Research Trust (ART), zimbabwe has developed non-toxic varieties of $J$. curcas, which would make the seed cake following oil extraction suitable as animal feed without its detoxification. Jatropha cultivation and management is poorly documented in South Africa and little field experience is available there. Currently, growers are unable to achieve the optimum economic benefits from the plant. The markets for the different products have not been properly explored or quantified, nor have the costs or returns (both tangible and intangible) to supply raw materials or products to these markets. Consequently, the 
actual or potentialgrowers including those in the subsistence sector do not have an adequate information base about the potential and economics of such plants to make decisions relating to their livelihood, not to mention its commercial exploitation.

Severe emission regulations in the world have placed design limitations on heavyduty diesel engines. The trend towards cleaner burning fuel is growing worldwide and this is possible through Jatropha based biodiesel. However, biodiesel from algae (currently stillin the early experimental stage), the second generation biofuel, may hold the promise of mass producing liquid fuels more sustainably than ethanol, soya biodiesel or any of the biomass, waste or fossilderived liquid fuel schemes. The Department of Energy, the United States has reported that biodiesel can be produced from algae in selfeontained ponds using salt water and sunlight as the main ingredients. Production of diesel from algae could be done for far less than the current cost of diesel (Ewall2006).

\section{Biodiesel: Socioeconomic implications}

The cultivations of biofuels species have several positive as well as negative socioeconomic implications. Some of the plant species appropriate for production of biofuels are capable of growing in arid, water stressed lands. Their cultivations also is less fertilizer and chemical intensive, which means that the farmers needs to invest lesser finances in their farms and they can make use of land that are not suitable for other crops including food crops. Since biofuels / biodiesel production can not be a house hold endeavor, appropriate institutional arrangements have to be developed. Appropriate sociallycommitted institutions are also very essential, to ensure financial security and returns are not at the mercy of the sponsoring biofuels producing firms or agencies.

A serious implication of the biofuels cultivation is the likelihood of good land suitable for other crops getting diverted to farm biofuels species. In the country that consumes the largest quantity of petroleum product and is responsible for the released of largest quantity of green house gas, the USA, food crops such as sugar 
cane, corn and wheat are diverted to produce bio-fuel.Biofuels based on food crops is disastrous to food availabilityworld over. Food Appropriate regulations needs to ensure that that type of diversions are not happening. However, one becomes very pessimistic in view of the sad plight of agriculturists in the country practicing the energy and chemical intensive farming practices and genetically modified crops such as BT cotton. The possible diversion of food crops for production of biofuels is also likely to deprive people of their accessibility to their food for sustenance. If cereals or land suitable for cereals are diverted for biofuels production that willlead to endanger large masses of access to essentialconsumer items or endanger their very sustenance.

\section{Conclusion}

As governments across the globe come to grips with global warming, biofuels are seen as a pragmatic step toward reducing carbon emissions. A growing number of countries now require various qualityassessments to ensure that the renewable fuel complies with approved specification and standards. Production of biofuel from plant materials is a major step toward harnessing one of the world's most-prevalent, yet least-utilized renewable energy resources. A breakthrough process for converting biomass into biodiesel fuel promises a cheaper way to go green. Eco-dreamers have long been hoping for a way to mitigating the global warming, but the slow pace of progress in alternative fuel technologies has remained a setback. The technologies available for biological conversion of cellulose biomass to biodiesel enjoy a high potential to succeed in the market. India, with its huge waste / nonfertilelands, has taken a well noted lead in the area and commercial production is where the industries have to focus on for selfsustainable development. India's biodiesel program has been based on Jatropha seeds only; but for reduced operating cost, a multiple feedstock-based strategy is needed. If the developed process is scaled up to commercial levels, itcould be a major step towards creation of an eco-friendly transportation fuel that is relatively clean on combustion and provides farmers with substantial income. Although presently both the developing and developed economies rely upon the wellknown firstgeneration biofuels, the step towards the second-generation biofuels could be a sound vision. The so-called 
second-generation biofuels show better ' average potential'but a number of first generation pathways look equally promising. The biofuels offer a bitof freedom from dependence on fossilfuels. Nevertheless, they also pose serious socioeconomic risk of depriving large masses of access to essential consumer items, including food, if proper attention and care is not given in promoting biofuels and profit motivated endeavors are given a free hand.

\section{References}

Alhasan M, Isah AG and Garba MU (2005). Production and Characterization of Biodiesel from Cottonseed Oil. The 6th Annual Engineering Conference S.E.E.T.F.U.T.Minna, 2005 .

Ananthakrishnan TN (1982). Bioresources Ecology, Volume 2. Oxford \& IBH Publishing Co. Pvt. Ltd.

ASTM D 6751. ASTM's Standard Specification for Biodiesel Fuel (B100) Blend Stock for DistillateFuels.

Canakci M and Gerpen JV (2001). Biodiesel production from oils and fats with high free fattyacid. Transactions of the ASAE.44 (6):1429-1436.

Coltrain D (2002). Biodiesel: Is itworth considering? In: The proceedings of 'Risk and Profit Conference,' Kansas State University, Holiday Inn, Manhattan, Kansas, August 15-16, 2002. 19 pp.

Cunningham WP and Cunningham MA (2002). Principles of Environmental Science: Inquiry and Applications. Mc Graw HillPublications, Boston, 418 pp.

Dorado MP, Ballesteros E, Almeida JA, Schellet C, Lohrlein HP and Krause R (2002). An alkalieatalyzed transesterification process for high free fatty acid oils.Transactions of the ASAE.45 (3):525-529.

Ewall M (2006). Fact Sheet: Biodiesel: Solution or Problem? Www.energyjustice.net as viewed on $9 / 14 / 2006$

Freedman B, Butterfield RO and Pryde EH (1986). Transesterification kinetics of soybean oil.Journal of American Oil and Chemical Society.63 $(10): 1375-1380$. 
Groschen R (No year).Energy balance/lifecycle inventory for ethanol, biodiesel and petroleum fuels. Minnesota Department of Agriculture. Downloaded September 2005. www.mda.state.mn.us/cgi-bin.

Hofman V, Wiesenborn D, Rosendahl M and Webster J (2006). Biodiesel use in engines. North Dakota State University, January 2006.8 pp.

Kurki A, Hill A and Morris M (2006). Biodiesel: The Sustainability Dimensions. ATTRA Publications, 12 pp.

Kusdiana D and Saka S (2001). Methyl esterification of free fatty acids of rapeseed oil as treated in supercritical methanol. Journal of Chemical Engineering of Japan.34 (3):373.

Meher LC, Vidya Sagar D and Naik SN (2006). Technical aspects of biodiesel production by transesterification - a review. Renewable and Sustainable Energy Reviews.10:248-268.

Mittelbach M (1996). Diesel fuel derived from vegetable oils, VI: Specifications and qualitycontrolof biodiesel.Bioresource Technology.27 (5):435-437.

Mittelbach M and Gangl S (2001). Long term storage stabilityof biodieselmade from rapeseed and used frying oil. Journal of American Oil and Chemical Society.78 (6):573-577.

Mohammed UG, Mohammed A and Abdulsalami SK (2006). A Review of Advances and Quality Assessment of Biofuels. Leonardo Journal of Sciences. 9: $167-178$.

Mohanraj R and Azeez PA (2005). Urban development and particulate air pollution in Coimbatore city, India. The International Journal of Environmental Studies.62 (1):69-78.

Peterson CL, Wagner GL and Auld DL (1983). Vegetable oilsubstitutes for diesel fuel.Transactions of the ASAE.26 (2):322-327.

Saka S and Kusdiana D (2001). Biodiesel fuel from rapeseed oil as prepared in supercriticalmethanol. Fuel. 80:225-231.

Schlautman NJ, Schinstock J L and Hanna MA (1986). Unrefined expelled soybean oilperformance in a diesel engine. Transactions of the ASAE.29 (1): $70-73$. 
Shanker C and Dhyani SK (2006). Insect pests of Jatropha curcas L. and the potentialfor theirmanagement. Current Science.91 (2):162-163.

Shay EG (1993). Diesel fuel from vegetable oil:status and opportunities.Biomass Bioenergy.4 (4):227-242.

Steenblik R (2006). Liberalization of Trade in Renewable Energy and Associated Technologies: Biodiesel, Solar Thermal and Geothermal Energy. OECD Trade and Environment Working Paper No. 2006-01, Organization for Economic Co-operation and Development, $28 \mathrm{pp}$.

Sudarsan KG and Anupama PM (2006). The relevance of biofuels. Current Science.90 (6):748-749.

Tickell J (2000). From the fryer to the fuel tank: the complete guide to using vegetable oil as an alternative fuel. $3^{\text {rd }}$ edition, Tickell Energy Consulting, Tallahassee, Florida. P. 36, 52-54.

Yong $\mathrm{H}$ (1998). Experimental research on cottonseed oil as alternative fuel for single-cylinder diesel engine. AMA. 29 (1):51-54.

Zhang $X$, Peterson C, Reece D, Haws R and Moller G (1998). Biodegradabilityof biodiesel in the aquatic environment, Transactions of the ASAE.41 (5): $1423-1430$. 